\title{
Pengaruh Naphthalene Acetic Acid (NAA) dan Kinetin terhadap Perkembangan Protocorm-Like Body (PLB) dan Regenerasi Anggrek Phalaenopsis sp. Hybrid
}

\author{
Didik Pudji Restanto ${ }^{1,2}$, Budi Kriswanto ${ }^{1}$, Nafisah Iqmatullah ${ }^{1}$, dan Parawita Dewanti ${ }^{1}$ \\ ${ }^{1}$ Laboratorium Kultur Jaringan, Prodi Agronomi, Fakultas Pertanian, Universitas Jember \\ ${ }^{2}$ Center for Development Advance Sciences and Technology (CDAST) Jember University \\ Jalan Kalimantan No. 37 Kampus Tegal Boto Jember \\ *Alamat korespondensi: restanto.lemlit@unej.ac.id
}

\begin{tabular}{|c|c|}
\hline INFO ARTIKEL & ABSTRACT/ABSTRAK \\
\hline Diterima: $\quad 05-02-2021$ & \\
\hline Direvisi: $\quad 11-06-2021$ & The Effect of Naphthalene Acetic Acid (NAA) and Kinetin on Protocorm-Like \\
\hline Dipublikasi:11-08-2021 & Body (PLB) Development and Regeneration of Phalaenopsis sp. Hybrid \\
\hline
\end{tabular}

Keywords:

Kinetin, NAA,

Phalaenopsis sp.

hybrid, Protocorm-like

body, Regeneration

Kata Kunci:

Kinetin, NAA,

Phalaenopsis sp.

hybrid, Protocorm-like

body, Regenerasi
Phalaenopsis is an orchid with high economic value due to its beautiful color. The demand of this orchid is increasing so that tissue culture technology is required in mass propagation of the orchid. Orchid propagation using a protocorm-like body (PLB) explant source is one of the best ways to produce large quantities of orchids. The study was aimed to identify the best combination of NAA and Kinetin in PLB development at liquid medium and the PLB that was subcultured in regeneration medium. The explant used was 2-month-old PLB that planted in liquid Vacin \& Went (VW) medium with combinations of NAA and Kinetin at concentrations of $2.5 \mathrm{mg} / \mathrm{L}, 5 \mathrm{mg} / \mathrm{L}$ and $7.5 \mathrm{mg} / \mathrm{L}$, respectively. The regeneration medium used was solid VW medium with supplements of 15\% coconut water, 5\% bananas, $5 \%$ potatoes and $0.2 \%$ activated charcoal. The experiment used a completely randomized design with three replications. The results showed that the combination of NAA and kinetin had no significant effect on the number and fresh weight of PLB. Meanwhile, almost all the combination showed the same colour of PLB, namely yellowish green (5GY 7/6), only the combination of NAA $5 \mathrm{mg} / \mathrm{L}+$ Kinetin $7.5 \mathrm{mg} / \mathrm{L}$ showed different result with pale yellow (5Y8/4) colour. The plantlet colour change from light yellowish green $(7.5 \mathrm{GY} 8 / 8)$ to yellowish green $(7.5 \mathrm{GY} 7 / 6)$ and dark yellowish green (7.5GY 6/10) occurred at the beginning of acclimatization and at two and four weeks. Orchid seedlings grew well and became mature plants after being transferred to black moss media.

Phalaenopsis merupakan anggrek yang mempunyai nilai ekonomis tinggi karena warna yang menarik. Permintaan selalu meningkat sehingga tehnologi kultur jaringan sangat dibutuhkan dalam perbanyakan anggrek ini. Perbanyakan tanaman anggrek menggunakan sumber eksplan protocormlike body (PLB) merupakan salah satu cara yang tepat untuk menghasilkan anggrek dalam jumlah banyak. Penelitian ini bertujuan untuk mendapatkan kombinasi NAA dan Kinetin terbaik pada perkembangan PLB di kultur cair serta PLB yang disubkultur di media regenerasi. Bahan tanam menggunakan PLB umur 2 bulan yang ditanam pada media Vacin \& Went (VW) cair dengan perlakuan kombinasi NAA dan Kinetin masing-masing pada konsentrasi 2,5 mg/L, $5 \mathrm{mg} / \mathrm{L}$ dan 7,5 mg/L. Media regenerasi menggunakan VW padat dengan suplemen $15 \%$ air kelapa, 5\% pisang, 5\% kentang dan 
0,2\% arang aktif. Percobaan menggunakan Rancangan Acak Lengkap dengan tiga kali ulangan. Hasil penelitian menunjukkan bahwa kombinasi NAA dan kinetin tidak berpengaruh terhadap jumlah dan berat PLB. Sementara itu, warna PLB hampir semua menunjukkan warna yang sama yaitu hijau kekuningan (5GY 7/6) hanya pada kombinasi perlakuan NAA $5 \mathrm{mg} / \mathrm{L}+$ Kinetin 7,5 mg/L terjadi klorosis berwarna kuning pucat (5Y8/4). Perubahan warna planlet terjadi dari hijau kekuningan terang (7.5GY8/8) menjadi hijau kekuningan (7.5GY7/6) dan hijau kekuningan tua (7.5GY6/10) masingmasing pada awal aklimatisasi, serta pada dua dan empat minggu. Bibit anggrek tumbuh dengan baik dan menjadi tanaman dewasa setelah dipindahkan pada media moss hitam.

\section{PENDAHULUAN}

Anggrek merupakan salah satu tanaman hias yang banyak dikembangkan dan diminati karena keindahannya dan tahan lama pada saat berbunga. Salah satu jenis anggrek yang banyak di budidayakan adalah anggrek Phalaenopsis hibrida (Hinsley et al., 2018). Menurut Meiliasari dan Iriawati (2016), anggrek Phalaenopsis hibrida merupakan salah satu anggrek yang memiliki nilai pasar yang tinggi sebagai tanaman hias. Anggrek ini merupakan salah satu jenis anggrek epifit monopodial yang sulit untuk dikembangkan secara vegetatif, tetapi mempunyai bunga yang bervariasi dan menarik sehingga berpotensi untuk dikembangkan secara masal dengan menggunakan tehnik kultur jaringan.

Kultur jaringan merupakan salah satu teknik perbanyakan tanaman dengan menumbuhkan mulai dari protoplas, sel atau jaringan tanaman dalam kondisi aseptik dalam waktu yang singkat (Gunawan, 1994). Sumber eksplan yang digunakan dalam kultur jaringan berupa organ yang berasal dari akar, batang, daun, biji dan embrio. Penambahan zat pengatur tumbuh (ZPT), vitamin, bahan organik, dan sukrosa mampu menunjang pertumbuhan tanaman secara in vitro (De \& Singh, 2018). Menurut Sarmah et al. (2017), keberhasilan dari kultur jaringan juga tergantung pada media (padat atau cair), ZPT dan sumber eksplan yang digunakan.

Perbanyakan tanaman anggrek menggunakan sumber eksplan protocorm-like body (PLB) merupakan salah satu cara yang tepat untuk menghasilkan anggrek dalam jumlah banyak. Secara umum PLB banyak digunakan sebagai eksplan karena memiliki kemampuan regenerasi yang tinggi. Perbanyakan dengan menggunakan PLB mampu menghasilkan planlet secara lengkap dalam waktu yang singkat (Kalyan \& Sujit, 2015). Menurut Setiari et al. (2018) PLB merupakan salah satu bagian dari tanaman anggrek yang terbentuknya tidak melibatkan pembentukan embrio seperti jaringan daun, batang, dan akar.

Media Vacin \& Went (VW) cair dengan penambahan NAA $5 \mathrm{mg} / \mathrm{L}$ dan kinetin $5 \mathrm{mg} / \mathrm{L}$ merupakan media terbaik untuk multiplikasi PLB dibandingkan dengan media VW padat dengan presentasi multiplikasi masing-masing $80 \%$ dan 70 \% (Park et al., 1996). Sementara itu, pemberian supplemen chitosan $15 \mathrm{mg} / \mathrm{L}$ memberikan hasil terbaik untuk jumlah PLB sebesar 12,33, berat basah PLB sebesar 0,88 g, serta jumlah planlet sekitar 6,66 (Restanto et al., 2016). Menurut Young et al. (2000), multiplikasi PLB anggrek Phalaenopsis sp. bisa ditingkatkan dari $20 \mathrm{~g}$ PLB yang identik dengan 1000 PLB bisa menjadi 18.000 PLB dalam waktu delapan minggu dan siap meregenerasi menjadi tanaman anggrek baru dengan menggunakan bioreaktor temporary immersion culture. Regenerasi bisa dilakukan dengan penambahan suplemen organik yang mampu mendorong perkecambahan PLB secara cepat (Utami \& Hariyanto, 2020).

\section{BAHAN DAN METODE}

Penelitian dilaksanakan di Laboratorium Kultur jaringan dan rumah kaca Fakultas Pertanian, Universitas Jember pada bulan Januari 2020 sampai Februari 2021. Penelitian ini dirancang menggunakan rancangan acak lengkap (RAL) dengan dua faktor yaitu NAA (tiga taraf: $2,5 \mathrm{mg} / \mathrm{L}, 5$ $\mathrm{mg} / \mathrm{L}$ dan $7,5 \mathrm{mg} / \mathrm{L}$ ) dan kinetin (tiga taraf: $2,5 \mathrm{mg} / \mathrm{L}$, $5 \mathrm{mg} / \mathrm{L}$ dan $7,5 \mathrm{mg} / \mathrm{L}$ ) sehingga terdapat sembilan kombinasi perlakuan yang diulang tiga kali. Di dalam satuan percobaan terdapat $0,5 \mathrm{~g}$ PLB sehingga total PLB yang digunakan sekitar 13,5 g.

Persiapan sumber eksplan dari selfing anggrek Phalaenopsis sp. Hybrid diawali dari 
penyerbukan sampai terbentuknya buah anggrek yang matang sekitar 6 bulan (Fang et al., 2016). Buah anggrek disterilisasi dengan merendam dalam alkhohol 96\% selama lima detik dan dibakar menggunakan api bunsen di dalam laminar dan diulang tiga kali. Buah anggrek yang telah steril diletakkan dalam cawan Petri kemudian dipotong kedua ujungnya dan dibuka dengan menggunakan scalpel. Biji anggrek kemudian ditanam pada media tebar VW padat dengan penambahan komposisi suplemen $20 \%$ air kelapa, $200 \mathrm{~mL}$ air rebusan kentang (100 g), satu mL liquinox (B1), satu mL atonik, dua $\mathrm{mL}$ minyak ikan dan pupuk daun gaviota dua g dalam satu L media. PLBs (small PLB) akan terbentuk sekitar dua bulan yang akan digunakan sebagai sumber eksplan.

PLB sebanyak $0,5 \mathrm{~g}$ yang identik dengan 65 PLB ditanam dalam media tebar (VW cair) dengan penambahan kombinasi hormon NAA dan kinetin sesuai perlakuan selama 10 minggu dan digojok menggunakan orbital shaker pada kecepatan 100 rpm. Regenerasi PLB dilakukan dengan menggunakan media VW padat yang ditambahkan suplemen organik kompleks berupa 15\% air kelapa, $5 \%$ homogenate pisang, $5 \%$ homogenat kentang, dan $0,2 \%$ arang aktif selama tiga bulan (Tawaro et al., 2008). Planlet anggrek kemudian diaklimatisasi dengan menggunakan moss hitam yang telah disterilkan menggunakan autoclave. Planlet dikeluarkan dari botol dan dibersihkan dari sisa agar yang menempel pada akar kemudian direndam dalam larutan fungisida M-45 dengan konsentrasi dua $\mathrm{g} / \mathrm{L}$ selama dua jam dan ditiriskan semalam. Planlet diaklimatisasi dengan cara kompot (community pot) selama empat minggu dan dipindah pada cup plastik secara individu.

Parameter yang diamati dalam penelitian ini yaitu tahap perkembangan PLB pada media cair dengan menggunakan mikroskop sterio LEICA pada pembesaran 8X, warna PLB dengan menggunakan skor muncell color charts, jumlah PLB dan berat PLB di akhir pengamatan. Tiga parameter pengamatan yang dilakukan pada tahap aklimatisasi yaitu jumlah daun, jumlah akar dan panjang akar dengan cara menghitung jumlah daun, jumlah akar dan panjang akar dibagi dengan jumlah planlet. Analisis data kuatitatif dengan menggunakan sidik ragan ANOVA dua arah kemudian kombinasi perlakuan yang menghasilkan pengaruh nyata dilakukan uji nilai tengah dengan menggunakan jarak berganda Duncan atau Duncan Multiple Range Test (DMRT) pada taraf kepercayaan 95\%.

\section{HASIL DAN PEMBAHASAN}

Sumber eksplan dalam penelitian ini yaitu PLB anggrek umur dua bulan dari tebar biji hasil selfing anggrek Phalaenopsis sp. Hybrid. Tanaman anggrek yang siap untuk di-selfing, perkembangan buah anggrek dan PLB umur dua bulan terlihat pada Gambar 1. Gambar 1 menunjukkan tahapan untuk mendapatkan sumber eksplan anggrek Phalaenopsis. Dimulai dengan persiapan anggrek Phalaenopsis sp. Hybrid yang telah berbunga sempurna dan telah siap untuk diserbuki sendiri, kemudian buah anggrek yang diperoleh ditebar setelah umur lima atau enam bulan, serta penyiapan PLB sebagai sumber eksplan yang terbentuk setelah berumur dua bulan.
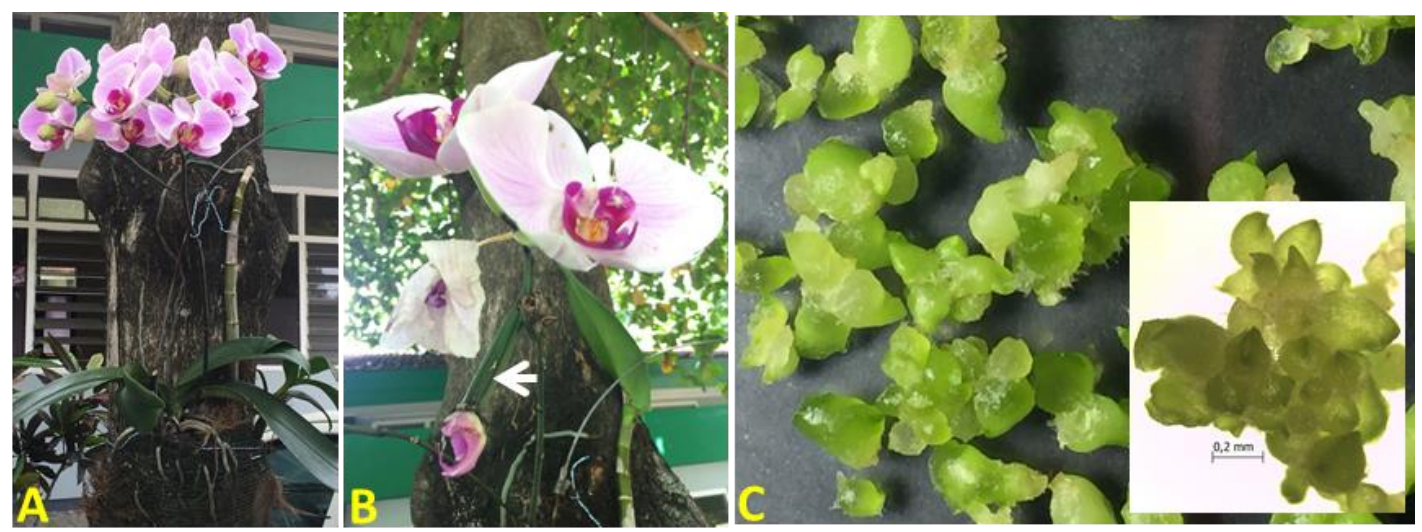

Gambar 1. Eksplan anggrek Phalaenopsis sp. Hybrid.

(A) Anggrek Phalaenopsis sp. Hybrid yang siap diserbuki sendiri (self pollination).

(B) Perkembangan buah anggrek Phalaenopsis (tanda panah) hasil selfing umur enam bulan. (C) PLB umur dua bulan sebagai sumber eksplan (Mikroskop sterio perbesaran 8X, skala 0,2 mm) 
Sumber eksplan berasal dari PLB yang berumur lima minggu sebesar $0,5 \mathrm{~g}$ yang identik dengan 65 PLB ditanam pada media VW cair. Selama dalam perlakuan media cair, PLB selalu tumbuh membentuk PLB anakan dan terdispersi karena penggojokan dalam orbitel shaker terlihat pada Gambar 2.
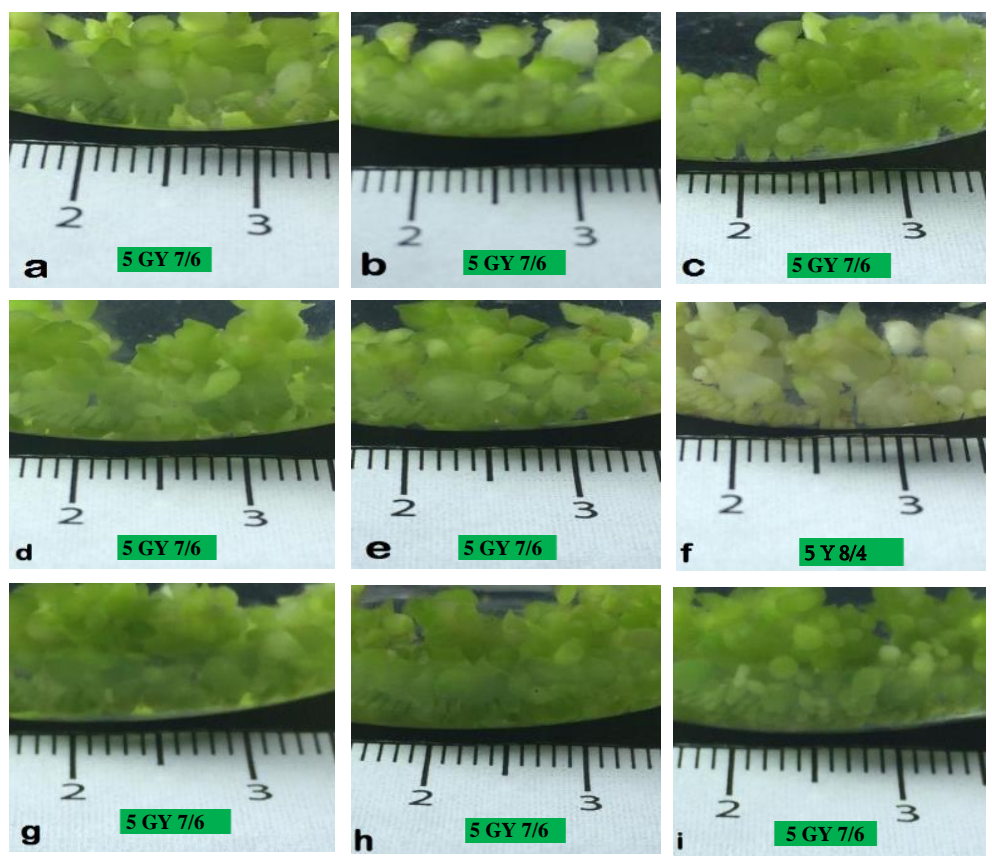

Gambar 2. PLB umur 5 minggu dalam media cair.

(a) NAA 2,5 mg/ L + Kinetin 2,5 mg/L. (b) NAA 2,5 mg/L + Kinetin $5 \mathrm{mg} / \mathrm{L}$.

(c) NAA 2,5 mg/L + Kinetin 7,5 mg/L. (d) NAA $5 \mathrm{mg} / \mathrm{L}+$ Kinetin $2,5 \mathrm{mg} / \mathrm{L}$.

(e) NAA $5 \mathrm{mg} / \mathrm{L}+$ Kinetin $5 \mathrm{mg} / \mathrm{L}$. (f) NAA $5 \mathrm{mg} / \mathrm{L}+$ Kinetin $7,5 \mathrm{mg} / \mathrm{L}$.

(g) NAA 7,5 mg/L + Kinetin 2,5 mg/L. (h) NAA 7,5 mg/L + Kinetin 5 mg/L.

(i) NAA 7,5 mg/L + Kinetin 7,5 mg/L.

Pada Gambar 2 terlihat bahwa PLB mempunyai warna yang sama pada semua kombinasi perlakuan berdasarkan munsell color chart dengan scor 5 GY 7/6, kecuali pada perlakuan kombinasi NAA 5 mg/L + Kinetin 7,5 mg/L yang menunjukkan warna yang berbeda cenderung kuning pucat dengan scor 5 Y 8/4 yang artinya PLB berwarna kuning pucat dengan value delapan dan chroma empat. Dari hasil analis warna menunjukkan semua kombinasi perlakuan mempunyai warna yang baik untuk PLB yaitu hijau kekuningan kecuali perlakuan NAA 5 mg/L + Kinetin 7,5 mg/L. Berdasarkan hasil yang sudah diperoleh menunjukkan bahwa kombinasi NAA dan Kinetin setiap perlakuan menghasilkan perkembangan PLB dengan respon yang baik. Hal ini terjadi karena kondisi sel yang telah mengalami pembesaran dan ZPT yang digunakan dalam media kultur juga berpengaruh terhadap munculnya PLB baru (Sitinjak dkk., 2015).

\section{Rata-rata Jumlah PLB}

Kombinasi antara NAA dan kinetin terhadap rata-rata jumlah PLB tidak menunjukkan perbedaan yang nyata (Gambar 3). Rata-rata jumlah PLB minggu ke-10 terlihat tidak menunjukkan perbedaan yang nyata. Rata-rata jumlah PLB pada kombinasi perlakukan empat yaitu NAA $5 \mathrm{mg} / \mathrm{L}+$ Kinetin 2,5 mg/ L sekitar 191 PLB, sedangkan pada kombinasi perlakuan sembilan yaitu NAA 7,5 mg/L + Kinetin 7,5 mg/L sekitar 108 PLB. Jumlah PLB akan meningkat sekitar 1,66-2,93 kali pada umur 10 minggu dibandingkan dengan sumber eksplan awal. 


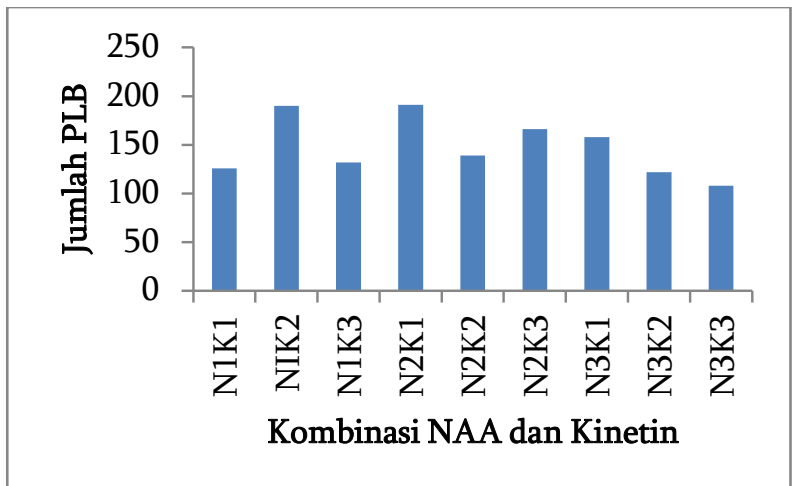

Gambar 3. Rata-rata jumlah PLB minggu ke-10 pada media cair.

$\mathrm{N} 1 \mathrm{~K} 1$ = NAA 2,5 mg/ L + Kinetin 2,5 mg/L. N1K2 = NAA 2,5 mg/L + Kinetin 5 mg/L. $\mathrm{N} 1 \mathrm{~K} 3$ = NAA 2,5 mg/L + Kinetin 7,5 mg/L. N2K1 = NAA 5 mg/L + Kinetin 2,5 mg/L.

N2K2 = NAA $5 \mathrm{mg} / \mathrm{L}$ + Kinetin $5 \mathrm{mg} / \mathrm{L}$. N2K3 = NAA $5 \mathrm{mg} / \mathrm{L}$ + Kinetin 7,5 mg/L. N3K1 = NAA 7,5 mg/L + Kinetin 2,5 mg/L. N3K2 = NAA 7,5 mg/L + Kinetin 5 mg/L.

$\mathrm{N} 3 \mathrm{~K} 3$ = NAA 7,5 mg/L + Kinetin 7,5 mg/L.

\section{Rata-rata Berat PLB}

Perlakuan kombinasi NAA 2,5 $\mathrm{mg} / \mathrm{L}+$ Kinetin $5 \mathrm{mg} / \mathrm{L}$ menghasilkan rata-rata berat PLB sebesar $1,84 \mathrm{~g}$, sedangkan pada perlakuan kombinasi NAA $2,5 \mathrm{mg} / \mathrm{L}$ + Kinetin 7,5 mg/L mempunyai ratarata berat PLB sekitar 1,33 g. Menurut (Kucera et al., 2005) adanya kombinasi auksin dan sitokinin berperan penting dalam perkembangan PLB.
Hormon auksin ini berpengaruh terhadap perkembangan PLB semakin besar karena mampu memicu sel PLB untuk terus berkembang, sedangkan hormon sitokinin mampu meningkatkan pembelahan sel terus menerus sehingga membuat berat PLB semakin bertambah. Rata-rata berat PLB pada minggu ke-10 juga tidak menunjukkan perbedaan yang nyata (Gambar 4).

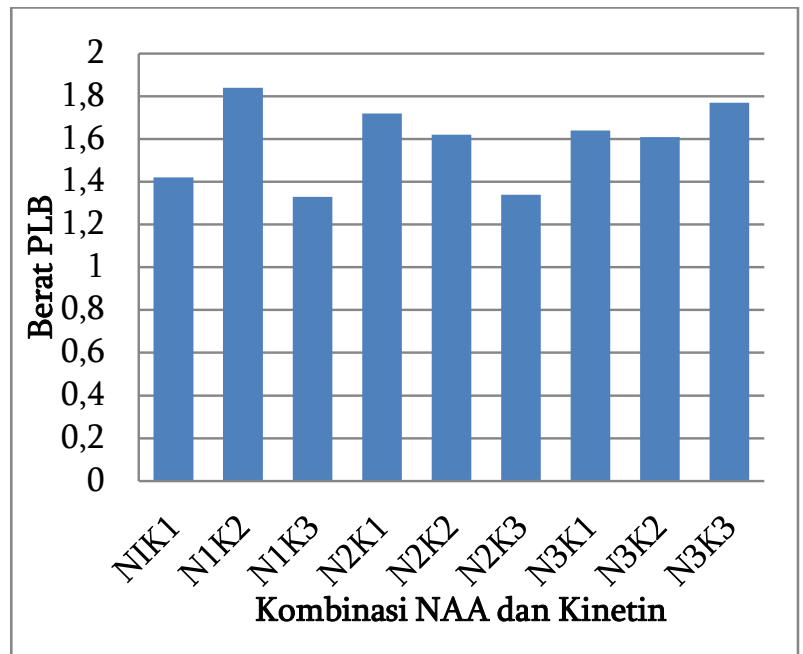

Gambar 4. Rata-rata berat PLB minggu ke-10 pada media cair.

$\mathrm{N} 1 \mathrm{~K} 1$ = NAA 2,5 mg/ L + Kinetin 2,5 mg/L. N1K2 = NAA 2,5 mg/L + Kinetin 5 mg/L.

N1K3 = NAA 2,5 mg/L + Kinetin 7,5 mg/L. N2K1 = NAA 5 mg/L + Kinetin 2,5 mg/L.

N2K2 = NAA 5 mg/L + Kinetin 5 mg/L. N2K3 = NAA 5 mg/L + Kinetin 7,5 mg/L.

N3K1 = NAA 7,5 mg/L + Kinetin 2,5 mg/L. N3K2 = NAA 7,5 mg/L + Kinetin 5 mg/L.

N3K3 = NAA 7,5 mg/L + Kinetin 7,5 mg/L.

\section{Pengamatan Mikroskopis}

Perkembangan PLB pada kultur cair umur 10 minggu menunjukkan perbedaan warna dan morfologinya (Gambar 5). Hasil analisis mikroskop sterio pada Gambar 5 menunjukkan bahwa setiap kombinasi perlakukan mempunyai skor warna yang sama yaitu hijau kekukingan (5 GY 7/6) kecuali pada kombinasi perlakuan (NAA $5 \mathrm{mg} / \mathrm{L}+$ Kinetin 2,5 
$\mathrm{mg} / \mathrm{L}$ ) yaitu kekuningan (5Y 8/4) terjadi klorosis (pucat). Klorofil dibutuhkan oleh tanaman dalam proses fotosintesis, secara tidak langsung akan berpengaruh dalam peningkatan regenerasi tanaman secara in vitro (Setiawati dkk., 2015).
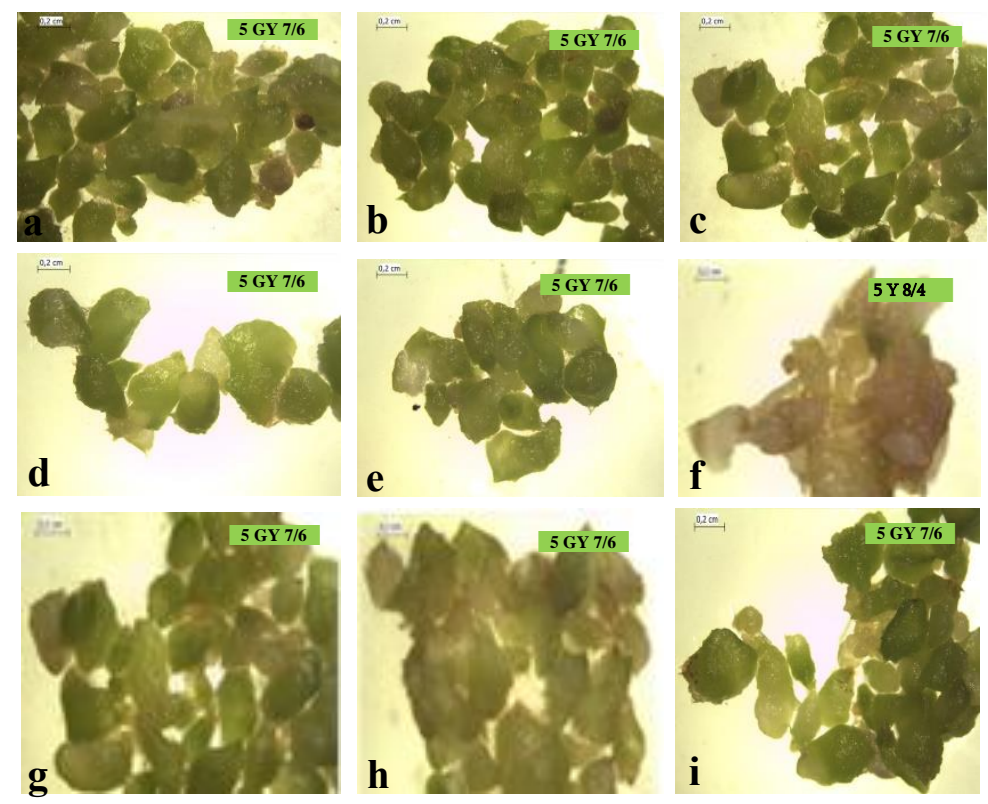

Gambar 5. PLB aggrek Phalaenopsis sp. setelah 10 minggu dalam media cair pada mikroskop perbesaran 8X.

(a) NAA 2,5 mg/ L + Kinetin 2,5 mg/L. (b) NAA 2,5 mg/L + Kinetin $5 \mathrm{mg} / \mathrm{L}$.

(c) NAA 2,5 mg/L + Kinetin 7,5 mg/L. (d) NAA $5 \mathrm{mg} / \mathrm{L}+$ Kinetin $2,5 \mathrm{mg} / \mathrm{L}$.

(e) NAA $5 \mathrm{mg} / \mathrm{L}+$ Kinetin $5 \mathrm{mg} / \mathrm{L}$. (f) NAA $5 \mathrm{mg} / \mathrm{L}+$ Kinetin 7,5 mg/L.

(g) NAA 7,5 mg/L + Kinetin 2,5 mg/L. (h) NAA 7,5 mg/L + Kinetin 5 mg/L.

(i) NAA 7,5 mg/L + Kinetin 7,5 mg/L.
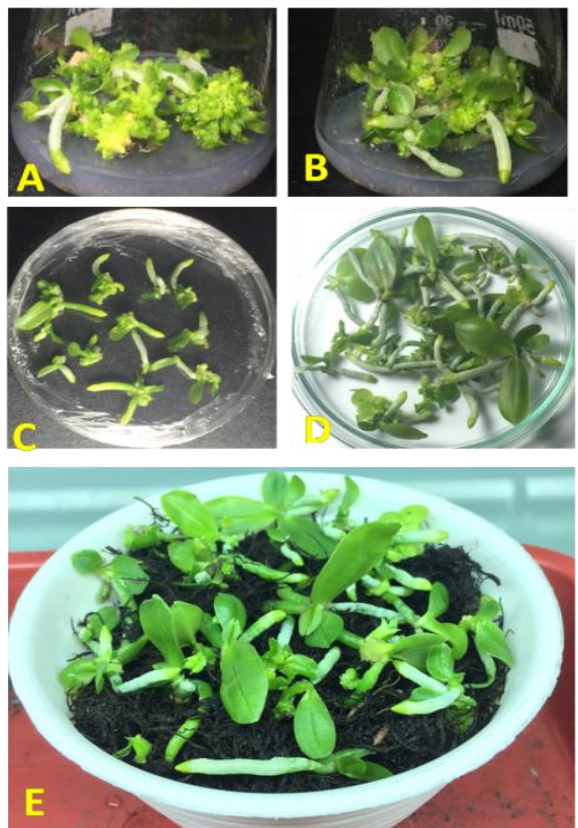

Gambar 6. Hasil regenerasi dan aklimatisasi Anggrek Phalaenopsis sp.

(A) Regenerasi pada umur enam MST. (B) Regenerasi pada umur Sembilan MST.

(C) Penjarangan planlet hasil regenerasi. (D) Planlet hasil regenerasi umur 12 MST yang siap diaklimatisasi.

(E) Aklimatisasi anggrek dengan menggunakan mos hitam di kompot selama satu bulan. 


\section{Regenerasi dan Aklimatisasi Anggrek}

Regenerasi dilakukan ketika PLB sudah 10 minggu berada di kultur cair. Selanjutnya PLB dipindah ke media regenerasi yaitu media VW padat dengan penambahan $15 \%$ air kelapa, $5 \%$ pisang, $5 \%$ kentang, dan $0,2 \%$ arang aktif. Komposisi bahanbahan tersebut merupakan media yang digunakan untuk memacu pertumbuhan dan perkembangan PLB untuk menjadi tanaman lengkap. Hasil regenerasi pada umur enam, sembilan dan 12 minggu dan aklimatisasi disajikan pada Gambar 6 .

Berdasarkan Gambar 6 terlihat bahwa hasil regenerasi pada umur enam MST sudah menunjukkan pertumbuhan daun yang diikuti dengan pertumbuhan akar. Planlet umur 9 MST menunjukkan pertumbuhan akar dan daun semakin banyak dan siap untuk dijarangkan. Setelah 12 MST planlet anggrek sudah tumbuh sempurna dan siap diaklimatisasi. Menurut Aktar et al. (2008) penambahan suplemen organik merupakan faktor yang penting untuk mempercepat pembentukan tunas dan akar anggrek.
Menurut Utami dan Hariyanto (2020) penambahan air kelapa dan ekstrak pisang mampu memperbaiki jumlah akar dan panjang akar, sehingga dengan adanya bahan organik ini pada media regenerasi mampu meningkatkan pertumbuhan planlet secara baik. Planlet hasil regenerasi umur 12 minggu masih mampu memunculkan PLB baru di sekitar sistem perakaran anggrek dan terus berkembang menjadi individu anggrek baru (Gambar 7). Anggrek terus membentuk daun dan perakaran baru. Banyaknya daun yang terbentuk ini terjadi karena peran auksin (air kelapa) yang mampu menambah jumlah daun (Nuraini et al., 2010). Gambar 7 menunjukkan planlet anggrek Phalaenopsis yang selalu membentuk PLB baru dapat diduga karena selalu mendapatkan nutrisi sehingga masih mempunyai kemampuan untuk tumbuh dengan baik pada posisi di pangkal perakaran anggrek seperti yang dilaporkan oleh Islam et al. (2015).
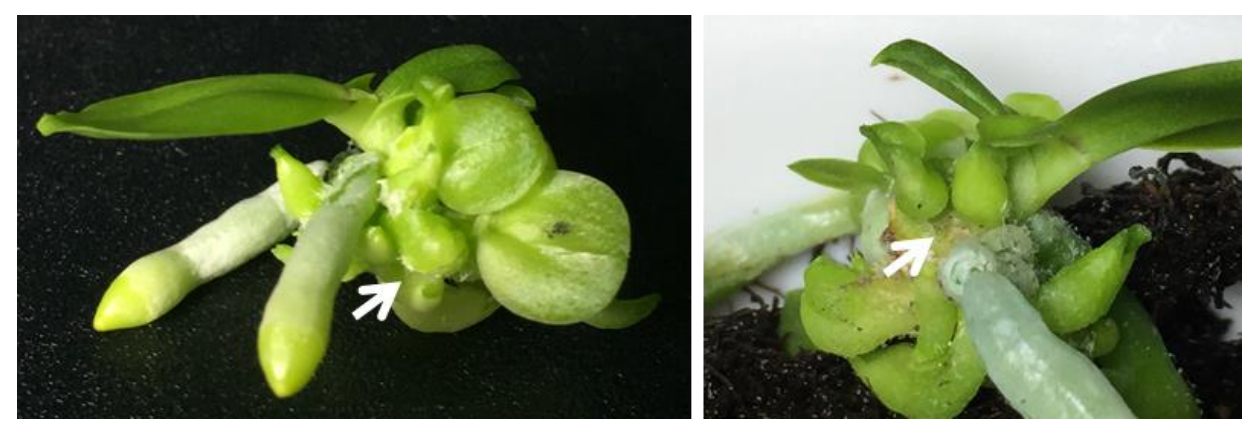

Gambar 7. PLB baru akan tumbuh pada pangkal perakaran anggrek (tanda panah).

Planlet yang siap diaklimatisasi adalah planlet yang sudah mempunyai minimal dua daun dan panjang akar sekitar 1,5-3,5 cm pada umur $12 \mathrm{MST}$ seperti terlihat pada Gambar 8. Pada Gambar 8 terlihat jumlah akar, panjang akar, dan jumlah daun dalam setiap botol kultur memiliki hasil yang berbeda. Rata-rata jumlah akar yang dihasilkan per eksplan nya yaitu 1,78 akar. Parameter rata-rata jumlah daun yaitu per eksplan sebesar 2,3, sedangkan untuk rata-rata panjang akar per eksplan yaitu 2,74 cm. Planlet anggrek kemudian diaklimatisasi (dikompotkan) pada media mos hitam yang telah disterilkan 0 minggu (awal aklimatisasi), umur dua mingu dan empat minggu dapat dilihat pada Gambar 9.

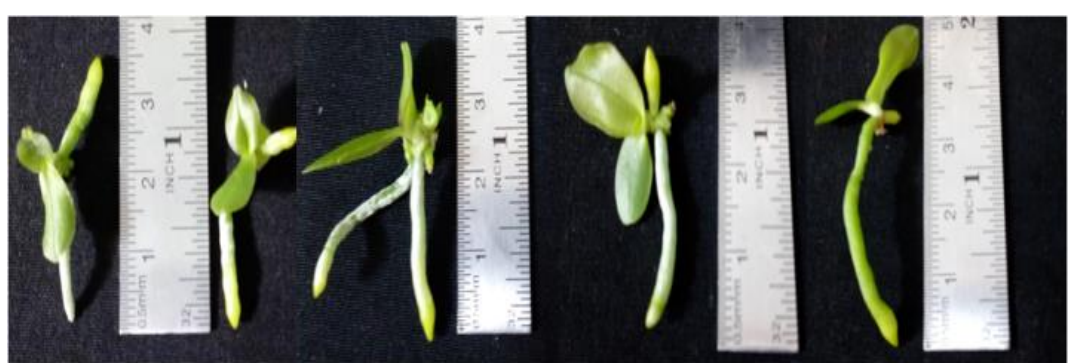

Gambar 8. Planlet yang dihasilkan dari PLB pada media regenerasi setelah 12 MST. 
Salah satu fase akhir dalam kultur jaringan adalah fase aklimatisasi. Fase aklimatisasi ini merupakan fase dimana planlet anggrek akan menyesuaikan dari lingkungan heterotrofik ke lingkungan autotrofik. Pertumbuhan secara vegetatif tanaman anggrek selama aklimatisasi akan dipengaruhi oleh sirkulasi udara, suhu, kelembaban, dan cahaya. Untuk memacu tumbuhan anggrek yang baik maka pada fase aklimatisasi tanaman anggrek diletakkan pada media pakis dan sabut kelapa. Gambar 9 menunjukkan hasil aklimatisasi pada umur yang berbeda. Planlet anggrek berwarna hijau kekuningan terang (7.5 GY 8/8) pada awal aklimatisasi, kemuadian berwarna hijau kekuningan (7.5 GY 7/6) pada umur dua minggu dan dan berwarna hijau kekuningan tua (7.5 GY 6/10) pada pengamatan empat minggu. Menurut Febriani et al. (2019) pertumbuhan anggrek yang semakin baik di media aklimatisasi dengan daun yang hijau menandakan kandungan klorofil yang tinggi, sehingga dengan kandungan klorofil yang tinggi tanaman anggrek dapat tumbuh dengan baik. Adanya pertumbuhan tanaman anggrek yang baik ini juga dipengaruhi adanya media aklimatisasi.

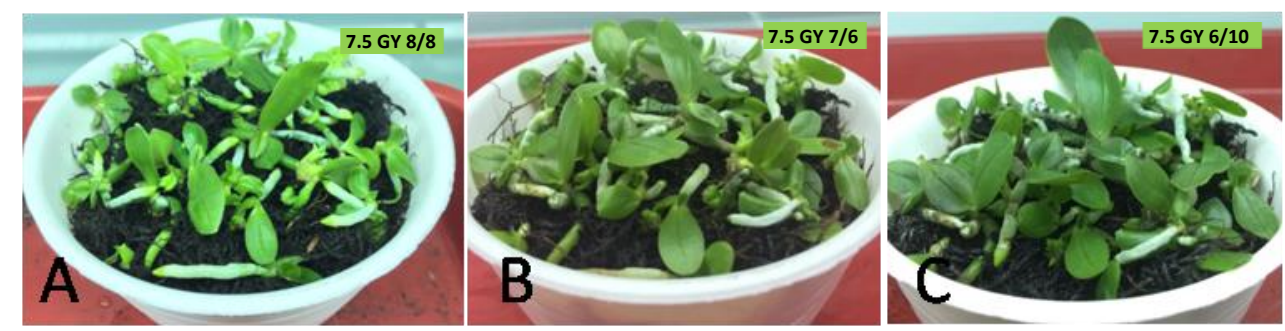

Gambar 9. Hasil Aklimatisasi Anggrek Phalaenopsis sp.

(A) Aklimatisasi Minggu ke-0 (awal aklimatisasi).

(B) Aklimatisasi minggu ke dua.

(C) Aklimatisasi minggu keempat.

Planlet anggrek setelah beradaptasi di media kompot selama 4 minggu kemudian dipindahkan pada media mos hitam yang telah disterilisasi secara individu untuk mempercepat pertumbuhan akar dan tunas (Gambar 10). Pertumbuhan bibit anggrek termasuk baik yang ditunjukkan oleh rata- rata jumlah daun yang mulai bertambah sekitar tiga atau empat daun dibandingkan awal aklimatisasi sekitar dua atau tiga daun. Demikian juga untuk perakaran sudah mulai berkembang (tanda panah) sehingga bibit anggrek akan tumbuh menjadi anggrek dewasa.

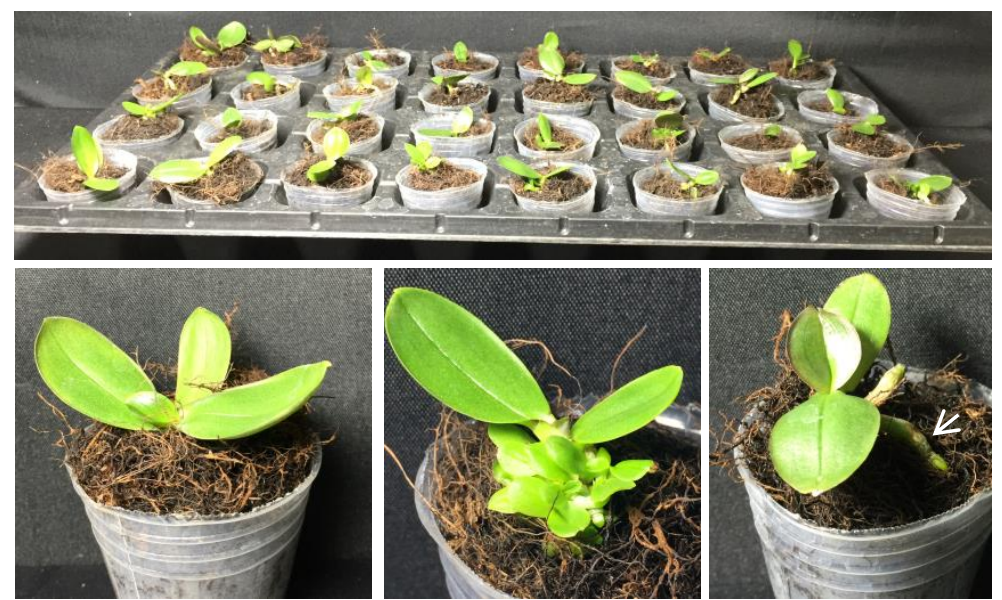

Gambar 10. Aklimatisasi pada media moss hitam secara individu pada umur 4 minggu.

\section{SIMPULAN}

Penambahan hormon kombinasi NAA dan kinetin masing-masing pada konsentrasi $2,5 \mathrm{mg} / \mathrm{L}, 5$ $\mathrm{mg} / \mathrm{L}$ dan 7,5 mg/L tidak berpengaruh terhadap jumlah PLB dan berat PLB pada media cair. Apabila dilihat dari warna PLB (Munsell color charts) selama di media cair hampir pada semua kombinasi 
perlakuan menunjukkan warna yang sama yaitu hijau kekuningan (5 GY 7/6), kecuali pada kombinasi perlakuan NAA $5 \mathrm{mg} / \mathrm{L}$ + Kinetin 7,5 $\mathrm{mg} / \mathrm{L}$ terjadi klorosis sehingga PLB berwarna kuning pucat (5Y 8/4). Perubahan warna planlet terjadi saat awal aklimatisasi di media kompot yaitu hijau kekuningan terang (7.5 GY 8/8), hijau kekuningan (7.5 GY 7/6) pada umur dua minggu dan hijau kekuningan tua (7.5 GY 6/10) pada umur empat minggu. Bibit anggrek tumbuh dengan baik setelah dipindahkan pada media moss hitam secara individu untuk menjadi tanaman dewasa.

\section{UCAPAN TERIMA KASIH}

Ucapan terima kasih kepada Laboratorium Kultur Jaringan, Fakultas Pertanian, Universitas Jember yang telah memfasilitasi penelitian ini dan DD orchid Batu Malang yang telah membantu bahan tanam angrek Phalaenopsis sp. Hybrid.

\section{DAFTAR PUSTAKA}

Aktar S, KM Nasiruddin, and K Hossain. 2008. Effects of different media and organic additives interaction on in vitro regeneration of Dendrobium orchid. Journal of Agricultural and Rural Development. 6: 69-74.

De, LC, and R Singh. 2018. Organic production of Cymbidium orchids. Acta Scientific Agriculture. 2(4): 30-35.

Febriani, S, DW Ganefianti, A Romeida, and R Herawati. 2019. Acclimatization of pencil orchid (Papillionanthe hookeriana Rehb.f) as affected by different types of planting media and fertilizing frequency. Akta Agrosia. 22(1): 36-41.

Fang, SC, JC Chen, and MJ Wei. 2016. Protocorms and protocorm-like bodies are molecularly distinct from zygotic embryonic tissues in Phalaenopsis Physiol. 171(4): 2682-270.

Gunawan, LW. 1994. Teknik Kultur Jaringan Tumbuhan. Penebar Swadaya. Jakarta.

Hinsley, AMY, HJD-E Boer, MF Fay, SW Gale, LM Gardiner, RS Gunasekara, and W Road. 2018. A review of the trade in orchids and its implications for conservation. Botanical Journal Of The Linnean Society. 3: 435-455.

Islam, O, MdS Islam, and MdA Saleh. 2015. Effect of banana extract on growth and development of protocorm like bodies in Dendrobium sp. orchid. The Agriculturists. 13(1): 101-108.

Kalyan, KDE, and S Sujit. 2015. Protocorm-like bodies and plant regeneration from foliar explants of Coelogyne flaccida, a horticulturally and medicinally important endangered orchid of Eastern Himalaya. LANKESTERIANA. 15(2): 151-158.

Kucera, B, MACohn, and G Leubner-metzger. 2005. Plant hormone interactions during seed dormancy release and germination. Seed Science Research. 15: 281-307.

Meiliasari, D, and I Iriawati. 2016. Regeneration of plantlets through PLB ( Protocorm-Like Body ) formation in Phalaenopsis 'Join Angle X Sogo Musadian'. J. Math. Fund. Sci. 48(3): 204-212.

Nuraini, A, WR Heriliya, E Suminar, dan E Marliana. 2010. Responses of protocorm like bodies hybrid Dendrobium orchid on various types and concentration of cytokinin and auxin on Murashige and Skoogs (MS) medium. Proceeding International Seminar on Horticulture to Support Food Security. Bandar Lampung. 22-23 June 2010. Pp. 130135.

Park, YS, SIAK Kakutaand, and M Okabe. 1996. Efficient propagation of protocorm-like bodies of Phalaenopsis in liquid medium. Tissue and Organ Culture. 45(1): 79-85.

Restanto, DP, B Santoso, B Kriswanto, and S Supardjono. 2016. The Application of chitosan for protocorm like bodies (PLB) induction of orchid (Dendrobium sp.) in vitro. Italian Oral Surgery. 9: 462-468.

Sarmah, D, S Kolukunde, and M Sutradhar. 2017. A Review on: In vitro cloning of orchids. International Journal of Current Microbiology and Applied Sciences. 6(9): 1909-1927.

Setiari, N, A Purwantoro, S Moeljopawiro, and E Semiarti. 2018. Micropropagation of Dendrobium phalaenopsis orchid through Overexpression of embryo gen AtRKD4. Agrivita. 40(2): 284-296.

Setiawati, Y, IA Astarini, dan NPA Astiti. 2015. Perbanyakan anggrek Dendrobium heterocarpum Lindl. secara in vitro dengan media yang berbeda. Jurnal Metamorfosa: Journal of Biological Sciences. 2(1): 34-40.

Sitinjak, MA, MN Isda, dan S Fatonah. 2015. Induksi kalus dari eksplan daun in vitro keladi tikus 
(Typhonium sp.) dengan perlakuan 2,4-D dan kinetin. Al-Kauniyah Jurnal Biologi. 8(1): 3239.

Tawaro, S, P Suraninpong, and S Chanprame. 2008. Germination and regeneration of Cymbidium findlaysonianum Lindl. on a medium supplemented with some organic sources. Walailak J Sci \& Tech. 5(2): 125-135.

Utami, ESW, and S Hariyanto. 2020. Organic compounds contents and their role in improving seed germination and protocorm development in orchids organic compounds: Contents and their role in improving seed germination and protocorm development in orchids. International Journal of Agronomy. 2020(2): 1-12.

Young, PS, HN Murthy, and PK Yoeup. 2000. Mass multiplication of protocorm-like bodies using bioreactor system and subsequent plant regeneration in Phalaenopsis. Plant Cell, Tissue and Organ Culture. 63(1): 67-72. 